\title{
ДИНАМІКА ЗМІН МІНЕРАЛЬНОГО СКЛАДУ МІКРО- ТА МАКРОЕЛЕМЕНТІВ КІСТКОВОЇ ТКАНИНИ СКРОНЕВО-НИЖНЬОЩЕЛЕПНИХ СУГЛОБІВ ПРИ ЦУКРОВОМУ ДІАБЕТІ
}

\begin{abstract}
Динаміка змін мінерального складу мікро- та макроелементів кісткової тканини скроневонижньощелепних суглобів при цукровому діабеті

\section{л. В. Рубас}

Тернопільський національний медичний університет імені І. Я. Горбачевського МОЗ України

Резюме. Цукровий діабет (ЦД) значно поширений у багатьох країнах світу. У хворих відзначається порушення мінерального обміну не лише в усьому організмі, а й у кістковій тканині зокрема, що призводить до остеопорозу, а відтак і до частих переломів, ранньої інвалідизації та смертності, через що ЦД визнаний експертами ВООЗ медико-соціальною епідемією XXI cm. Однак у науковій літературі немає даних щодо змін мінеральних речовин скронево-нижньощелепних суглобів (СНЩС) при ЦД.

Мета дослідження - встановити динаміку змін мінерального складу мікро- та макроелементів кісткової тканини СНЩС при иукровому діабеті.

Матеріали і методи. Експериментальне дослідження здійснено на 90 білих статевозрілих щурах-самцях масою 90-320 г, яких утримували на раціоні віварію. Тварин поділили на 6 груп по 15 щурів у кожній. Самцям першої, другої та третьої груп моделювали цукровий діабет иляхом одномоментного введення стрептозотоцину «Sigma». Щурів четвертої, п'ятої та шостої груп використовували у якості контролю у відповідні терміни дослідження. Забій тварин здійснювали через 1, 2 та 3 місяці від початку експерименту, після чого проводили забір комплексів СНЩС та прилеглих м'яких тканин з обох боків. Для проведення спектрофотометрії попіл кісток СНЩС готували за методикою О. Г. Бабенка. Для проведення аналізу отриманий попіл розчиняли в $10 \%$ соляній та азотній кислотах і доводили бідистильованою водою до 25 мл. Комп'ютерна система полум'яного атомного абсорбційного спектрофотометра С-115 розраховує концентрації макро- та мікроелементів у дослідних розчинах. Вміст фроссрору визначали на ФЕК-2 за методикою Брігса.

Результати. Дані спектрофотометричного дослідження СНЩС щурів вказують на зниження рівня неорганічних речовин у кістковій тканині з одночасним збереженням кількості органічних речовин та значним збільшенням ступеня гідратації. Поряд з цим відзначається підвищення рівня одних мікроелементів (калію, натрію, магнію) та зниження інших (кальцію, фоссрору, купруму, мангану).
Dynamics of changes of the mineral composition of micro- and macroelements of bone tissue of the temporomandibular joints in diabetes

\section{V. Rubas}

I. Horbachevsky Ternopil National Medical University e-mail: rebuxalv@tdmu.edu.ua

Summary. Diabetes mellitus (DM) is widespread in many countries of the world. It influences on mineral metabolism not only throughout the body but also in bone tissue in particular, which leads to osteoporosis, and therefore to frequent fractures, early disability and mortality. However, there is no data in the scientific literature on changes in the minerals of the temporomandibular joints (TMJ) in diabetes.

The aim of the study - to establish the dynamics of changes in the mineral composition of micro- and macroelements of TMJ bone tissue in diabetes mellitus.

Materials and Methods. The experimental study was performed on 90 white adult male rats weighing 90-320 g, which were kept in the diet of the vivarium. The animals were divided into 6 groups of 15 rats each. Males of the groups 1, 2, 3 were simulated diabetes mellitus by a single injection of streptozotocin "Sigma". Rats of the groups 4, 5, 6 were used as controls at the appropriate time of the study. Animals were slaughtered 1, 2 and 3 months after the start of the experiment, followed by sampling TMJ complexes and adjacent soft tissues from both sides. For spectrophotometry of bone ash TMJ was prepared according to the method of $\mathrm{O}$. $\mathrm{H}$. Babenko. For analysis, the resulting ash was dissolved in $10 \%$ hydrochloric acid and nitric acids and adjusted with double-distilled water up to $25 \mathrm{ml}$. Flammable nuclear computer system absorption spectrophotometer C-115 calculates concentrations of macro- and microelements in experimental solutions. The phosphorus content was determined on FEC-2 by the method Briggs.

Results. Data from spectrophotometric studies of rat $T M J$ indicate a decrease in the level of inorganic substances in bone tissue while maintaining the amount of organic matter and a significant increase in the degree of hydration. Along with this, there is an increase in the level of some trace elements (potassium, sodium, magnesium) and a decrease in others (calcium, phosphorus, copper, manganese). 
Висновки. Демінералізація кісткової тканини СНЩС щурів, що проявляється у змінах рівнів макрота мікроелементів, веде до розвитку остеопорозу, а відтак і до деструктивних захворювань даних суглобів.

Ключові слова: мікроелементи; макроелементи; цукровий діабет; стрептозотоцин; скронево-нижньощелепний суглоб; спектрофотометрія.

\section{ВСТУП}

Цукровий діабет (ЦД) значно поширений у багатьох країнах світу. Дане захворювання характеризується хронічною гіперглікемією, зумовленою недостатньою секрецією, дією інсуліну або ж обидвома цими чинниками одночасно. У таких хворих відзначається порушення мінерального обміну не лише в усьому організмі, а й у кістковій тканині зокрема $[1,2]$. Інсулінодефіцит знижує синтез лужної фоосфатази та остеобластного колагену, що призводить до перетворення органічного фроссрору в неорганічний та до порушення глікозаміногліканового складу кісткової тканини [3, 4]. При ЦД збільшується рівень ПТГ, а відтак підвищується резорбція кісток [5]. Надлишок глюкози негативно впливає на клітини кісткової тканини, напряму ушкоджуючи їх. Підвищення синтезу цитокінів призводить до імунозапальних реакцій, що, у свою чергу, посилюють резорбцію кісткової тканини. Такі зміни у гомеостазі мінерального обміну призводять до остеопорозу, а відтак і до частих переломів, ранньої інвалідизації та смертності [6, 7]. Через це ЦД визнаний експертами ВООЗ медико-соціальною епідемією XXI ст. Однак в науковій літературі немає даних щодо змін мінеральних речовин скроневонижньощелепних суглобів (СНщС) при ЦД.

Метою дослідження було встановити динаміку змін мінерального складу мікро- та макроелементів кісткової тканини скронево-нижньощелепних суглобів при цукровому діабеті за результатами експериментального дослідження.

\section{МАТЕРІАЛИ I МЕТОДИ}

Дослідження було виконано на базі центральної науково-дослідної лабораторії Тернопільського національного медичного університету імені І. Я. Горбачевського МОЗ України. Всі експерименти проводили згідно з умовами та правилами біоетики, передбачених Європейською конвенцією про захист хребетних тварин, які використовуються для експериментів та інших наукових цілей, Загальними етичними принципами експериментів на тваринах та Гельсинською декларацією Генеральної асамблеї Всесвітньої медичної асоціації.

Експериментальне дослідження здійснено на 90 білих статевозрілих щурах-самцях масою 90320 г, яких утримували на раціоні віварію. Тварин
Conclusions. Demineralization of the TMJ bone tissue of rats with diabetes, which is manifested in changes in the levels of macro- and microelements, leads to the development of osteoporosis, and therefore to destructive diseases of these joints.

Key words: microelements; macroelements; diabetes mellitus; streptozotocin; temporomandibular joint; spectrophotometry.

поділили на 6 груп по 15 щурів у кожній. Самцям першої, другої та третьої груп моделювали цукровий діабет шляхом одномоментного введення стрептозотоцину «Sigma» внутрішньочеревно у розрахунку 50 мг/кг. Період спостереження за даними тваринами тривав 30; 60 та 90 діб відповідно. Щурів четвертої, п'ятої та шостої груп використовували у якості контролю у відповідні терміни дослідження [8]. Забій щурів здійснювали через 1, 2 та 3 місяці від початку експерименту шляхом кровопускання під наркозом тіопенталу натрію у розрахунку 25 мг/кг, після чого проводили забір комплексів СНЩС та прилеглих м'яких тканин $з$ обох боків.

Для проведення спектрофотометрії попіл кісток СНЩС готували за методикою О. Г. Бабенка [9]. Для запобігання потрапляння мікроелементів у пробу посуд та інструментарій вимивали дистильованою водою. Кістки СНЩС старанно очищали від м'яких тканин і промивали бідистильованою водою. Матеріал поміщали в попередньо доведені до сталої маси порцелянові тиглі та ставили на аналітичні ваги для визначення сирої маси кісток. Тиглі з кістками підсушували в термостаті при температурі $105^{\circ} \mathrm{C}$ до постійної маси. Зважували тиглі з висушеним матеріалом на аналітичних вагах. За різницею у масі вологих та сухих кісток визначали їх вологість. Висушену тканину в порцелянових тиглях спалювали при температурі $450{ }^{\circ} \mathrm{C}$ у мусрельній печі. Мінералізацію вважали закінченою, коли попіл ставав злегка забарвленим або білим. Шляхом зважування охолоджених тиглів із попелом визначали загальну кількість мінеральних речовин у сухому залишку. Попіл добували 3 тиглів неметалевим шпателем та зберігали в малих щільно закритих пробірках.

Для проведення аналізу отриманий попіл розчиняли в $10 \%$ соляній та азотній кислотах і доводили бідистильованою водою до 25 мл. Комп'ютерна система полум'яного атомного абсорбційного спектрофоотометра С-115 (модернізованого ффірмою SEO) розраховує концентрації макро- та мікроелементів у досліджуваних розчинах. Вміст фоссрору визначали на ФЕК-2 за методикою Брігса [10].

Статистичну обробку отриманих результатів здійснювали за допомогою програми Microsoft Excel, а достовірність результатів оцінювали за коефріцієнтом Стьюдента. 


\section{РЕЗУЛЬТАТИ Й ОБГОВОРЕННЯ}

Результати спектрофотометричного дослідження складу мікро- та макроелементів кісток СНЩС щурів показали, що в динаміці розвитку стрептозотоциніндукованого цукрового діабету кількість неорганічних речовин зменшувалась, а органічних - залишалась майже незмінною (табл.). Водночас спостерігалось підвищення ступеня гідратації кісткової тканини.

Ми встановили чіткі зміни у складі мікроелементів. Причому відзначалось статистично достовірне зниження вмісту кальцію, фроссрору, купруму та мангану. Втрата цих елементів свідчить про демінералізацію кісткової тканини з можливим розвитком її остеопорозу. Водночас спостерігалось підвищення рівня таких мікроелементів, як калій, магній та натрій. Збільшення вмісту цих мікроелементів має замінне значення.

При цукровому діабеті спостерігається порушення кровопостачання та обмінних процесів у кістковій тканині СНщС. Зниження вмісту кальцію спричинене збільшенням рівня паратгормону, за допомогою якого руйнується білкова матриця кістки. При цьому кальцій вивільняється в кров та розвивається гіперкальціємія. Водночас із збільшенням вмісту паратгормону в організмі гальмується процес оборотної реабсорбції фоосфору, а інсулінодесріцит знижує перетворення органічного фросфору в неорганічний. Вагому роль у підтримці кислотно-лужної рівноваги відіграє K-Na баланс, порушення якого може бути зумовлено гідратацією кісткової тканини, яка була підтверджена спектрофотометрично.

Таким чином, проведені спектрофротометричні дослідження кісткової тканини СНЩС свідчать про її демінералізацію в динаміці розвитку цукрового діабету, що може призвести до деструктивних явищ в даному суглобі та спричинити в майбутньому різноманітні захворювання СНЩС.

Таблиця. Результати спектрофотометричного дослідження кісток скронево-нижньощелепних суглобів білих щурів у нормі та при моделюванні стрептозотоциніндукованого цукрового діабету (M $\pm \mathrm{m})$

\begin{tabular}{|c|c|c|c|c|c|c|c|c|c|c|}
\hline \multirow[b]{2}{*}{$\begin{array}{c}\text { Тривалість спосте- } \\
\text { реження }\end{array}$} & \multicolumn{10}{|c|}{ Параметр } \\
\hline & Вода, \% & $\begin{array}{l}\text { Орган. } \\
\text { р-ни, \% }\end{array}$ & $\begin{array}{l}\text { Неорг. } \\
\text { р-ни, \% }\end{array}$ & $\begin{array}{c}\mathrm{K}^{+}, \\
\% \text { на } \\
\text { сухий } \\
\text { зали- } \\
\text { шок }\end{array}$ & $\begin{array}{c}\mathrm{Na}^{+}, \\
\% \text { на } \\
\text { сухий } \\
\text { зали- } \\
\text { шок }\end{array}$ & $\begin{array}{c}\mathrm{Ca}^{2+}, \\
\% \text { на } \\
\text { сухий } \\
\text { зали- } \\
\text { шок }\end{array}$ & $\begin{array}{c}\mathrm{P}^{+}, \\
\% \text { на } \\
\text { сухий } \\
\text { зали- } \\
\text { шок }\end{array}$ & $\begin{array}{c}\mathrm{Cu}^{2+}, \\
\% \text { на } \\
\text { сухий } \\
\text { зали- } \\
\text { шок }\end{array}$ & $\begin{array}{c}\mathrm{Mg}^{+}, \\
\% \text { на } \\
\text { сухий } \\
\text { зали- } \\
\text { шок }\end{array}$ & $\begin{array}{c}\mathrm{Mn}^{+}, \\
\% \text { на } \\
\text { сухий } \\
\text { зали- } \\
\text { шок }\end{array}$ \\
\hline $\begin{array}{l}\text { Контроль, } \\
1 \text { місяць }\end{array}$ & $\begin{array}{c}22,40 \pm \\
0,07\end{array}$ & $\begin{array}{c}35,17 \pm \\
0,03\end{array}$ & $\begin{array}{c}64,90 \pm \\
0,03\end{array}$ & $\begin{array}{c}0,87 \pm \\
0,1\end{array}$ & $\begin{array}{c}1,22 \pm \\
0,01\end{array}$ & $\begin{array}{c}37,61 \pm \\
0,4\end{array}$ & $\begin{array}{c}17,00 \pm \\
0,15\end{array}$ & $\begin{array}{c}21,30 \pm \\
0,20\end{array}$ & $\begin{array}{c}4,13 \pm \\
0,04\end{array}$ & $\begin{array}{c}12,79 \pm \\
0,10\end{array}$ \\
\hline $\begin{array}{l}\text { Експеримент, } \\
1 \text { місяць } \\
\end{array}$ & $\begin{array}{c}22,0 \pm \\
0,13 \\
\end{array}$ & $\begin{array}{c}34,98 \pm \\
0,02 \\
\end{array}$ & $\begin{array}{c}65,13 \pm \\
0,11 \\
\end{array}$ & $\begin{array}{c}0,88 \pm \\
0,01 \\
\end{array}$ & $\begin{array}{c}1,27 \pm \\
0,01 \\
\end{array}$ & $\begin{array}{c}37,00 \pm \\
0,28 \\
\end{array}$ & $\begin{array}{c}15,67 \pm \\
0,10 \\
\end{array}$ & $\begin{array}{c}21,18 \pm \\
0,22 \\
\end{array}$ & $\begin{array}{c}4,28 \pm \\
0,04 \\
\end{array}$ & $\begin{array}{c}12,70 \pm \\
0,09 \\
\end{array}$ \\
\hline $\begin{array}{l}\text { Контроль, } \\
2 \text { місяці } \\
\end{array}$ & $\begin{array}{c}22,39 \pm \\
0,04\end{array}$ & $\begin{array}{c}35,10 \pm \\
0,02 \\
\end{array}$ & $\begin{array}{c}64,97 \pm \\
0,02\end{array}$ & $\begin{array}{c}0,89 \pm \\
0,01 \\
\end{array}$ & $\begin{array}{c}1,21 \pm \\
0,01 \\
\end{array}$ & $\begin{array}{c}37,62 \pm \\
0,35 \\
\end{array}$ & $\begin{array}{c}17,02 \pm \\
0,14\end{array}$ & $\begin{array}{c}21,33 \pm \\
0,20\end{array}$ & $\begin{array}{c}4,16 \pm \\
0,04 \\
\end{array}$ & $\begin{array}{c}12,82 \pm \\
0,12 \\
\end{array}$ \\
\hline $\begin{array}{l}\text { Експеримент, } \\
2 \text { місяці }\end{array}$ & $\begin{array}{c}23,67 \pm \\
0,09\end{array}$ & $\begin{array}{c}35,05 \pm \\
0,12\end{array}$ & $\begin{array}{c}64,98 \pm \\
0,12\end{array}$ & $\begin{array}{c}0,93 \pm \\
0,01\end{array}$ & $\begin{array}{c}1,30 \pm \\
0,01\end{array}$ & $\begin{array}{c}34,64 \pm \\
0,23\end{array}$ & $\begin{array}{c}15,24 \pm \\
0,15\end{array}$ & $\begin{array}{c}20,07 \pm \\
0,20\end{array}$ & $\begin{array}{c}4,47 \pm \\
0,03\end{array}$ & $\begin{array}{c}12,49 \pm \\
0,09\end{array}$ \\
\hline $\begin{array}{l}\text { Контроль, } \\
3 \text { місяці }\end{array}$ & $\begin{array}{c}21,99 \pm \\
0,10\end{array}$ & $\begin{array}{c}34,88 \pm \\
0,04\end{array}$ & $\begin{array}{c}65,25 \pm \\
0,10\end{array}$ & $\begin{array}{c}0,90 \pm \\
0,01\end{array}$ & $\begin{array}{c}1,21 \pm \\
0,01\end{array}$ & $\begin{array}{c}38,02 \pm \\
0,38\end{array}$ & $\begin{array}{c}17,41 \pm \\
0,15\end{array}$ & $\begin{array}{c}21,33 \pm \\
0,18\end{array}$ & $\begin{array}{c}4,19 \pm \\
0,04\end{array}$ & $\begin{array}{c}12,83 \pm \\
0,11\end{array}$ \\
\hline $\begin{array}{l}\text { ксперимент, } \\
\text { місяці }\end{array}$ & $\begin{array}{c}25,98 \pm \\
0,13\end{array}$ & $\begin{array}{c}36,03 \pm \\
0,14\end{array}$ & $\begin{array}{c}64,18 \pm \\
0,32\end{array}$ & $\begin{array}{c}0,98 \pm \\
0,01\end{array}$ & $\begin{array}{c}1,36 \pm \\
0,01\end{array}$ & $\begin{array}{c}31,77 \pm \\
0,27\end{array}$ & $\begin{array}{c}14,87 \pm \\
0,13\end{array}$ & $\begin{array}{c}19,740 \\
0,19\end{array}$ & $\begin{array}{c}4,67 \pm \\
0,04\end{array}$ & $\begin{array}{c}12,44 \pm \\
0,10\end{array}$ \\
\hline
\end{tabular}

\section{ВИСновки}

1. Демінералізація кісткової тканини скроневонижньощелепних суглобів щурів проявляється у змінах рівнів макро- та мікроелементів та веде до розвитку остеопорозу, а відтак і до деструктивних захворювань даних суглобів.

2. У динаміці розвитку цукрового діабету кількість неорганічних речовин зменшувалась, органічних - залишалась майже незмінною, а також спостерігалось підвищення ступеня гідратації кісткової тканини, що підтверджено спектрофотометричним дослідженням.

3. В основі деструкції кісткової тканини скронево-нижньощелепних суглобів лежать зміни ії мінерального складу. Спектрофотометричне дослідження підтвердило прогресивну втрату кальцію, фоссрору, купруму та мангану, що може бути спричинена діабетичними ангіопатіями та порушенням обмінних процесів організму.

\section{СПИСОК ЛІТЕРАТУРИ}

1. Пестун І. С. Особливості репаративного остеогенезу при переломах трубчастих кісток у хворих на цукровий діабет : робота на здобуття кваліфікаційного ступеня магістра ; спец.: 14.01.38 - загальна практика- сімейна медицина / І. С. Пестун. - Суми : СумдУ; мед. ін-т, 2016. - 36 с.

2. Журавльова Л. В. Зміни показників метаболізму кісткової тканини у хворих на остеоартроз та при його 
поєднанні з цукровим діабетом 2-го типу / Л. В. Журавльова, М. О. Олійник // Досягнення та перспективи експериментальної і клінічної ендокринології (П'ятнадцяті Данилевські читання) : матеріали наук.-практ. конфр. 3 міжнар. участю, Харків, 10-11 березня 2016 р. / ДУ Iнститут проблем ендокринної патології ім. В. Я. Данилевського НАМН України, Харківський національний медичний університет, Харківська медична академія післядипломної освіти МОЗ України. - 2016. - С. 35-36.

3. Хандога В. С. Променева діагностика змін скелета нижніх кінцівок при цукровому діабеті : робота на здобуття кваліфікаційного ступеня магістра ; спец.: 14.01.23 - радіологія / В. С. Хандога. - Суми : СумдУ; мед. ін-т, 2016. - 50 c.

4. Германчук С. М. Зміни в альвеолярному відростку при хронічній фразі модельованого цукрового діабету (терміном 3 місяці) / С. М. Германчук // Український журнал медицини, біології та спорту. - 2018. - № 2(3). С. 21-25.

5. Сафрарова С. С. Оценка ремоделирования костной ткани у пациентов с сахарным диабетом 2 типа / С. С. Сафрарова // Запорожский медицинский журнал. - 2019. - № 1(21). - C. 60-63. DOI: 10.14739/23101210.2019.1.155812

\section{REFERENCES}

1. Pestun IS. Features of reparative osteogenesis in tubular bone fractures in patients with diabetes. Master's thesis, Sumy State University; 2016. Ukrainian.

2. Juravliova LV, Oliinyk MO. Changes in bone metabolism in patients with osteoarthritis and its combination with type 2 diabetes mellitus. Achievements and prospects of experimental and clinical endocrinology (Fifteen Danilevsky's readings): materials of the scientificpractical conference with international participation, Kharkiv, March 10-11, 2016; SI Institute of Endocrine Pathology. V.Ya. Danilevsky National Academy of Medical Sciences of Ukraine, Kharkiv National Medical University, Kharkiv Medical Academy of Postgraduate Education of the Ministry of Health of Ukraine. Kharkiv, 2016. Ukrainian.

3. Khandoga VS. Radiation diagnosis of changes in the skeleton of the lower extremities in diabetes mellitus Master's thesis. Sumy: Sumy State University; Med. Inst. 2016. Ukrainian.

4. Germanchuk SM. [Changes in the alveolar sprout in the chronic phase of simulated diabetes mellitus (for 3 months)]. Ukr zhurn med, boil i sport. 2018;(3, 2): 21-5. Ukrainian.
6. Сыкал А. А. Минеральная плотность кости у женщин с сахарным диабетом 2 типа / А. А. Сыкал // Актуальные направления научных исследований: от теории к практике. - Чебоксары, 2015. - С. 60-63.

7. Оценка риска перелома у пациентов с сахарным диабетом 2 типа / А. Н. Хвисюк, А. А. Сыкал, В. А. Бабалян, А. В. Кальченко // Ортопедия, травматология и протезирование. - 2015. - № 2. - С. 35-41.

8. Абрамов А. В. Кількісний аналіз проліферативної активності тканин пародонту щурів після екстракції зуба на фроні експериментального цукрового діабету / А. В. Абрамов, К. С. Ганчев // Клініч. та експерим. патологія. - 2019. - T. 18, № 1 (67). - C. 10-15. DOI: 10.24061/1727-4338.XVIII.1.67.2019.199

9. Хопта Н. С. Вплив солей кадмію та нітритів на метаболізм у кістковій тканині : авторефр. дис. на здобуття наук. ступеня канд. біол. наук : 03.00.04 / Хопта Надія Степанівна ; Нац. акад. аграр. наук України, ін-т біології тварин. - Львів, 2015. - 24 с.

10. Якимець М. М. Морфоорункціональні особливості ремоделювання пародонта при гіперглікемії (клініко-експериментальне дослідження): дис. ... канд. мед. наук : 14.03.01 / Якимець Мар'яна Миколаївна ; Держ. вищ. навч. закл. «Терноп. держ. мед. ун-т ім. І. Я. Горбачевського». - Тернопіль, 2011. - 176 с.

5. Safarova SS. [Evaluation of bone remodeling in patients with type 2 diabetes mellitus]. Zaporozh med zhurn. 2019;(21,1): 60-3. DOI: 10.14739/23101210.2019.1.155812. Russian.

6. Sykal AA. [Bone mineral density in women with type 2 diabetes]. Current areas of research: from theory to practice. 2015;(1): 60-3. Russian.

7. Khvisyuk AN, Sykal AA, Babalyan VA, Kalchenko AV. [Fracture risk assessment in patients with diabetes mellitus]. Ortop, travm i prop. 2015;(2): 35-41. Russian.

8. Abramov AV, Ganchev KS. [Quantitative analysis of proliferative activity of rats' periodontal tissues after tooth extraction on the background of experimental diabetes mellitus]. Klin i eksperym patol. 2019;(18,(1): 10-5. DOI: 10.24061/1727-4338.XVIII.1.67.2019.199. Ukrainian.

9. Hopta NS. Influence of cadmium salts and nitrites on metabolism in bone tissue. Candidate's thesis. National Academy of Agrarian Sciences of Ukraine, Institute of Biology of Animals. 2015. Ukrainian.

10. Yakymets MM. Morphofunctional features of periodontal remodeling in hyperglycemia (clinicalexperimental study). Candidate's thesis. I.Ya. Horbachevsky Ternopil State Medical University. 2011. Ukrainian. 